http://nv.nltu.edu.ua

https://doi.org/10.15421/40280507

Article received 21.05.2018 $p$.

Article accepted 31.05.2018 p.

\title{
ФЛОРИСТИЧНИЙ АНАЛІЗ ЕПІГЕЙНОЇ ЛІХЕНОБІОТИ ФІТОЦЕНОЗІВ АСОЦІАЦІЇ CLADONIO-PINETUM JURASHEК В УМОВАХ ЗАХІДНОГО ПОЛІССЯ
}

\begin{abstract}
Лишайникові бори є об'єктами охорони європейських екомереж, тому актуальним і невідкладним завданням на сьогодні $\epsilon$ їх докладне вивчення і на теренах України. Сухі соснові бори займають незначну площу у лісовому фонді Західного Полісся і є рідкісними фітоценозами, у наземному вкритті яких домінують лишайники. За результатами аналізу польових матеріалів та гербарних зразків проведено флористичний аналіз ліхенобіоти фітоценозів асоціації Cladonio-Pinetum Jurashek на території Західного Полісся. Здійснено систематичний аналіз ідентифікованих видів лишайників та встановлено, що усі вони належать до двох родин - Cladoniaceae Zenker та Parmeliaceae Zenker і двох родів - Cladonia Hill. ex P. Browne та Cetraria Ach. Визначені види лишайників належать до мультирегіонального геоелемента бореального типу ареалу. Використано методи екологічної оцінки видів лишайників та розподілу їх за вимогливістю до чинників середовища (тип субстрату, вологість, трофність грунту, освітлення, антропогенний вплив). Встановлено, що епігейні лишайники сухого соснового бору за рівнем кислотності грунту є субацидофілами, нейтрофілами; за вимогливістю до родючості грунту усі види $є$ оліготрофами; за реакцією на зволоженість субстрату є ксерофітами; за реакцією на світловий режим є геліофітами; за реакцією на антропогенний вплив більшість видів $є$ олігогемеробами та мезогемеробами. Результати флористичного аналізу можуть бути підгрунтям для проведення моніторингових досліджень епігейної ліхенобіоти фітоценозів асоціації Cladonio-Pinetum Jurashek в умовах Західного Полісся.
\end{abstract}

Ключові слова: систематика лишайників; епігейні лишайники; Cladonio-Pinetum Jurashek; Cladonia Hill.; Західне Полісся.

Вступ. Особливим типом соснового бору $є$ лишайниковий бір, який у фітосоціологічній класифікації має назву Cladonio-Pinetum Juraszek 1927, а за лісотипологічною класифікацією - сухий сосновий бір. Такий тип лісу найчастіше трапляється у центральній та північній частинах Західного Полісся. Цінність таких фітоценозів полягає у найбагатшому видовому складі наземних кущистих лишайників родів Cladonia та Cetraria (Wójciak, 2003). Лишайники є екологічно пластичнішими порівняно $з$ рослинами, що дає їм змогу рости на найрізноманітніших субстратах. Зважаючи на бідність умов сухого бору видовий склад вищих судинних рослин є дуже обмеженим.

Багато видів епігейних лишайників є характерними для певних рослинних угруповань, тому цілком доречним є вивчення ліхенобіоти у різних типах біотопів, де вони найчастіше трапляються. Дослідження такого типу є фундаментальними під час складання прогнозів змін лісових угруповань загалом і соснової формації зокрема.

Епігейні лишайники в сухих соснових борах домінують у наземному вкритті, а отже, їх вплив на насадження, порівняно $з$ іншими епіфітними та епілітними лишайниками, є істотним. Тому вивчення складу, структури та динаміки лишайникового вкриття може бути основою для комплексного моніторингу та ліхеноінди- кації стану сухих соснових борів різних категорій захисності. Здійснений флористичний моніторинг ліхенобіоти можна використати для дослідження взаємозалежностей між лишайниковим вкриттям і сосновими деревостанами в умовах сухого бору.

На сьогодні відомостей про флористичний аналіз епігейної ліхенобіоти на усій території Західного Полісся у літературних джерелах не виявлено. Опубліковані матеріали містять дані про видовий склад епігейних лишайників тільки на окремих територіях. Відомості про ліхенобіоту Західного Полісся містяться у публікаціях В. Р. Маслової (Maslova, 1972-1977; Fedorenko, 2005, 2006). Зокрема, вона досліджувала закономірності розміщення та видовий склад лишайників як типових, так і нових для Полісся, а також вперше пов'язала видовий склад лишайників із основними лісовими формаціями.

Значний внесок у дослідження ліхенобіоти Поліського регіону зробив А. М. Окснер, який вперше подав інформацію про точне місцезростання видів лишайників. Його праця "Флора лишайників України" містить дуже важливу інформацію щодо діагностики видів, детальний опис родин та родів лишайників, а також ключі для їх ідентифікації (Oxner, 1993). М. В. Пірогов на території Шацького НПП виявив 20 видів епігейних лишайників (Pirogov, 2009-2013). Для всіх ідентифікованих видів лишайників наведено географічні координати

\section{Інформація про авторів:}

Мерцало Мирослава Вікторівна, аспірант, кафедра ботаніки, деревинознавства та недеревних ресурсів лісу. Email: myrvik@ukr.net

Цитування за ДСтУ: Мерцало М. В. Флористичний аналіз епігейної ліхенобіоти фітоценозів асоціації Cladonio-Pinetum Jurashek в умовах Західного полісся. Науковий вісник НЛтУ України. 2018, т. 28, № 5. С. 35-38.

Citation APA: Mertsalo, M. V. (2018). Floristic analysis of epigeous lichenobyota of Cladonio-Pinetum Juraszek in Western polissya. Scientific Bulletin of UNFU, 28(5), 35-38. https://doi.org/10.15421/40280507 
місць збирання та описано типи субстратів, на яких вони росли.

Матеріали і методи дослідження. Флористичний аналіз передбачав розподіл видів лишайників за групами на основі найрізноманітніших критеріїв і складався із систематичного, географічного, екологічного та біоморфологічного аналізів ліхенобіоти Західного Полісся.

Експериментальні матеріали для проведення флористичного аналізу отримано внаслідок моніторингу епігейної ліхенобіоти у фітоценозах асоціації CladonioPinetum Juraszek, 1927 та дослідження колекції видів лишайників. Дослідний матеріал зібрано впродовж п'яти років (2014-2018 рр.) на пробних площах, які рівномірно розташовані на території Західного Полісся. Дослідження здійснювали для вивчення сучасного стану, поширення, проблем збереження та відновлення лишайникових соснових борів у цьому регіоні. Аналіз зібраних зразків лишайників проведено в лабораторних умовах відповідно до загальноприйнятих методик, наведених у публікаціях, пов'язаних із дослідженнями ліхенофлори України (Oxner, 1993; Yatzyna, 2012).

Результати дослідження. За результатами власних досліджень та аналізу гербарного матеріалу ідентифіковано 14 видів епігейних лишайників, які належать до царства Fungi, відділу Ascomycota, підвідділу Euascomycotina, класу Lecanoromycetes O. E. Erikss. \& Winka, підкласу Ostropomycetidae Reeb, Lutzoni \& Cl. Roux, порядку Agyriales Clem. \& Shear, 2 родин (Cladoniaceae Zenker та Parmeliaceae Zenker), 2 родів (Cladonia Hill. ex P. Browne та Cetraria Ach.,), 2 підродів (Cladonia та Cladina (Nyl.) Leight. em. Vain.); 4 секцій (Cocciferae (Del.) Vain.; Cladonia; Unciales (Del.) Oxn.; Cladina); 3 підсекцій (Cocciferae (Del.) Matt.; Thallostelides (Vain.) Matt.; Cladonia).

Використовуючи класифікаційну систему, яку запропонував А. М. Окснер, здійснено систематичний розподіл ідентифікованих видів лишайників (Oxner, 1993).

Систематична структура епігейної ліхенобіоти сухого соснового бору:

Родина 1. Cladoniaceae Zenker

Рід 1. Cladonia Hill. ex Р. Browne

Підрід 2. Cladonia (Vain.)

Секція 1. Cocciferae (Del.) Vain.

Підсекція 2. Cocciferae (Del.) Matt.

Cladonia deformis (L.) Hoffm.,

Cladonia coccifera (L.) Willd.,

Секція 3. Cladonia (Del.) Vain.

Підсекція 3. Thallostelides (Vain.) Matt.

Cladonia gracilis (L.) Willd.,

f. leucochlora Floerk. ex Vain.,

var. dilatata (Hoffm.) Vain.,

Cladonia cornuta (L.) Schaer.,

Cladonia subulata (L.) Wigg.,

Cladonia coniocraea (Floerk.) Spreng.

Підсекція 4. Cladonia (Del.) Vain.

Cерія 1. Cladonia (Vain.) Matt.

Cladonia furcata (Huds.) Schrad.,

Cladonia rangiformis Hoffm.,

Секція 4. Unciales (Del.) Oxn.

Cladonia uncialis (L.) Web. ex Wigg. em. Hoffm.

Підрід 4. Cladina (Nyl.) Leight. em. Vain.

Секція 6. Cladina (Vain.)

Cladonia rangiferina (L.) Web. ex Wigg.,

Cladonia sylvatica (L.) Hoffm.,
Cladonia mitis Sandst.,

Cladonia phyllophora Hoffm.

Родина 1. Parmeliaceae Zenker

Рід 1. Cetraria Ach.

Cetraria islandica (L.) Ach.

Географічну структуру ліхенобіоти проаналізовано iз застосуванням зонально-регіональної класифікації (Oxner, 1993). Встановлено, що епігейні лишайники Західного Полісся належать до трьох типів ареалів мультирегіонального геоелемента:

- гіпоарктомонтанного типу ареалу (Cladonia cornuta, C. deformis, C. subulata);

- бореального типу ареалу (Cladonia coccifera, C. coniocraea, C. gracilis, C. mitis, C. rangiferina, C. sylvatica, C. uncialis, C. phyllophora, Cetraria islandica);

- евриголарктичного типу ареалу (Cladonia chlorophaea, C. rangiformis, C. furcata).

Найважливішими методами оцінювання екології видів рослин і угруповань $\epsilon$ аналіз їх розподілу залежно від чинників середовища, таких як тип субстрату, вологість, трофність грунту, освітлення та ін. Окремі чинники середовища мають вирішальне значення для існування лишайників, натомість інші лише опосередковано впливають на їх появу і ріст.

Досліджені лишайники сухого соснового бору за типом субстрату відносять до епігейних видів, оскільки вони ростуть на грунті, рослинних рештках та відкритих коренях дерев. Підстилка і гумусовий горизонт у таких біотопах складаються із опаду хвої, кори та гілок сосни, які в процесі розкладу підвищують кислотність грунту. Зважаючи на це, визначені види наземних лишайників за реакцією на кислотність субстрату є субацидофілами, і тільки Cladonia rangiformis належать до нейтрофілів. Сухі соснові бори сформувались на бідних піщаних грунтах, які погано затримують вологу, тому всі ідентифіковані види лишайників за рівнем трофності відносять до оліготрофів, а за реакцією на зволоженість субстрату є ксерофітами. Як встановлено за результатами досліджень, вирішальним чинником, від якого залежить видовий склад лишайників, інтенсивність їх росту та розповсюдження, $є$ рівень освітлення під наметом деревостану. Найвищу видову різноманітність лишайників встановлено у низько- та середньоповнотних деревостанах. Зважаючи на це, лишайники сухого соснового бору за реакцією на світловий режим відносять до геліофітів. Лишайники є досить вразливими до механічних пошкоджень, особливо в сухому стані, тому легко піддаються антропогенній деструкції. Наслідки такого пошкодження можуть проявлятись як у момент пошкодження, так і в майбутньому. За реакцією на антропогенний вплив більшість видів є олігогемеробами, що ростуть у ценозах, у яких антропогенний вплив незначний, а такі види, як Cladonia gracilis, C. rangiformis, C. subulata можуть рости в антропогенно змінених вторинних рослинних угрупованнях і є мезогемеробами (Oxner, 1968; Pirogov, 2010).

Встановлено, що лишайники є симбіотичними організмами, які утворені грибом (мікобіонт) і водоростями або ціанобактеріями (фотобіонт). Епігейні лишайники родів Cladonia та Cetraria є двох-трьохкомпонентними, оскільки складаються з гриба одного виду (Ascomycetes) і ціанобактерії або водорості, або з гриба і двох видів фотобіонтів. 
Біоморфологічні особливості епігейних лишайників зумовлюють особливості їх росту і розвитку. За морфологічною будовою талому всі види відносять до типових кущистих лишайників, а також кущистих лишайників 3 перехідними формами (рис.).
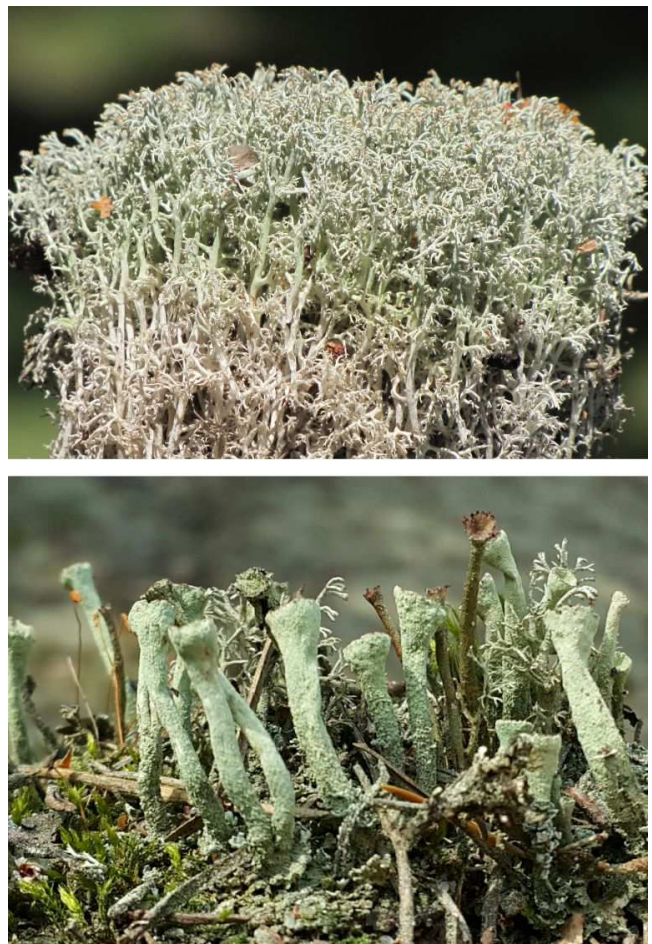

Рисунок. Cladonia rangiferina - кущиста форма; Cladonia deformis - перехідна форма

Кущисту форму талому мають лишайники Cladonia rangiferina, C. sylvatica, C. furcata, C. mitis, C. uncialis, C. phyllophora, C. rangiformis, Cetraria islandica, а перехідну форму - Cladonia cornuta, C. deformis, C. subulata, C. coccifera, C. coniocraea, C. gracilis. Лишайники роду Cladonia відрізняються від решти кущистих лишайників особливою будовою, у них виділяють нижню первинну листувату слань, з якої виростають вертикальні гілочки або подеції, які утворюють вторинну слань. Первинна слань може зберігатися протягом усього життя лишайника.

Анатомічна будова таких лишайників $\epsilon$ досить складною. За будовою талому всі ідентифіковані види лишайників $є$ гетеромерними. Для них характерна високоорганізована слань, яка утворена п'ятьма анатомічними шарами: два шари плектенхіми, два гонідіальні шари та серцевина.
Висновки. За результатами флористичного аналізу епігейної ліхенобіоти фітоценозів асоціації Cladonio-Pinetum Jurashek в умовах Західного Полісся встановлено, що:

- систематична структура ліхенобіоти представлена 14 видами кущистих лишайників з родин Cladoniaceae Zenker та Parmeliaceae Zenker, та родів Cladonia Hill. ex P. Browne та Cetraria Ach.;

- географічна структура представлена видами мультирегіонального геоелемента із переважанням бореального типу ареалу;

- екологічна структура ліхенобіоти сухих соснових борів свідчить, що ідентифіковані види є: епігейними; субацидофілами, нейтрофілами; оліготрофами; ксерофітами; геліофітами, олігогемеробами та мезогемеробами;

- за анатомічною будовою ці види є гетеромерними, а за формою талому всі види є кущистими з перехідними формами.

\section{Перелік використаних джерел}

Fedorenko, N. M. (2005). Stan vyvchenosti lyshainykiv Ukrainskoho Polissia. [State of study of lichens of Ukrainian Polissya]. Ukr. botan. zhurn., 2(62), 183-189. [In Ukrainian].

Fedorenko, N. M., Kondratiuk, S. Ya., \& Orlov, O. O. (2006). Lyshainyky ta likhenofilni hryby Zhytomyrskoi oblasti. [Lichen-forming and lichenicolous fungi of Zhytomyr region]. Kyiv-Zhytomyr: Ruta-Volyn. 147 p. [In Ukrainian].

Iatcyna, A. P. (2012). Taksonomicheskii analiz lishainikov sosnovykh lesov Belarusi. [Taxonomic analysis of lichens of pine forests of Belarus]. Sbornik nauchnykh trudov, 41, 63-77. [In Russian].

Maslova, V. R. (1972). Lyshainyky osnovnykh lisovykh formatsii Zakhidnoho Polissia. [The lichens of the main forest formations of Western Polissya]. Ukrainskyi botanichnyi zhurnal, 3(29), 304 308. [In Ukrainian].

Maslova, V. R. (1977). Lyshainyky Poliskoho zapovidnyka. [Lichens of the Polissya Reserve]. Ukrainskyi botanichnyi zhurnal, 1(34), 55-61. [In Ukrainian].

Oksner, A. M. (1993). Flora lyshainykiv Ukrainy. [Flora of lichens of Ukraine]. Kyiv: Nauk. dumka. 541 p. [In Ukrainian].

Pirogov, N. V. (2013). Lishainiki i likhenofilnye griby Shatckogo Natcionalnogo prirodnogo parka (Ukraina). [Lichens and lichenicolous fungi of Shatsk National Natural Park (Ukraine)]. Zarzadzanie Ochrona przyrody w lasach., 7, 94-108. [In Russian].

Pirohov, M. V. (2010). Lyshainyky rodyny Peltigeraceae Dumort. na Ukrainskomu Roztochchi. [Linchens of Paltigeraceae Dumort. family on Ukrainian Roztochya]. Studia Biologica, 1(4), 83-94. [In Ukrainian].

Wójciak, H. (2003). Porosty, mszaki, paprotniki. [Lichens, mosses, ferns]. Warshawa: MULTICO. 368 p. [In Polish].

\title{
ФЛОРИСТИЧЕСКИЙ АНАЛИЗ ЭПИГЕЙНОЙ ЛИХЕНОБИОТЫ ФИТОЦЕНОЗОВ АССОЦИАЦИИ CLADONIO-PINETUM JURASHЕК В УСЛОВИЯХ ЗАПАДНОГО ПОЛЕСЬЯ
}

\begin{abstract}
Лишайниковые боры являются объектами охраны в европейских экосетях, поэтому актуальным и неотложным на сегодня является детальное их изучение на территории Украины. Сухие сосновые боры занимают незначительную площадь в лесном фонде Западного Полесья и являются редкими фитоценозами, в наземном покрытии которых доминируют эпигейные лишайники. По результатам анализа полевых материалов и гербарных образцов осуществлен флористический анализ лихенобиоты. Осуществлено систематическое распределение идентифицированных видов лишайников и установлено, что все они относятся к двум семействам Cladoniaceae Zenker и Parmeliaceae Zenker двух родов Cladonia Hill. ex P. Browne и Cetraria Ach. Идентифицированные виды лишайников относятся к мультирегиональному геоэлементу с преобладанием бореального типа ареала. Использовав методы экологической оценки видов лишайников, осуществлено распределение их по требовательности к факторам среды (тип субстрата, влажность, трофность почвы, освещенность, антропогенное воздействие). Установлено, что эпигейные лишайники сухого соснового бора по требовательности к уровню кислотности почвы относятся к субацидофилам, нейтрофилам; по требовательности к плодородию почвы все виды являются олиготрофными;
\end{abstract}


за реакцией на влажность субстрата относятся к ксерофитам; по реакции на световой режим относятся к гелиофитам; по реакции на антропогенное воздействие большинство видов является олигогемеробами и мезогемеробами. Результаты флористического анализа могут быть основой для проведения мониторинговых исследований эпигейной лихенобиоты фитоценозов ассоциации Cladonio-Pinetum Jurashek в условиях Западного Полесья.

Ключевые слова: систематика лишайников; эпигейные лишайники; Cladonio-Pinetum Jurashek; Cladonia Hill.; Западное Полесье.

M. V. Mertsalo

Ukrainian National Forestry University, Lviv, Ukraine

\section{FLORISTIC ANALYSIS OF EPIGEOUS LICHENOBYOTA OF CLADONIO-PINETUM JURASZEK IN WESTERN POLISSYA}

Dry pine forests are rare phytocoenoses and in Western Polissya they occupy a small area. Phytosociological association Cladonio-Pinetum Juraszek 1927, where lichens are quite abundant in the ground vegetation, takes a special place among these dry pine forests. This association, in the European ecological network NATURA 2000 is considered to be a priority habitat deserving strict protection, and thus it is an important subject to study it in detail, in Ukraine as well. The value of such phytocoenoses is in the richest species composition of the terrestrial bush lichens of the gender Cladonia and Cetraria. Many kinds of epigeous lichens are characteristic of certain plant associations, so it is appropriate to study the lichenobyota in different types of biotopes, where it is most commonly encountered. Floristic monitoring of lichenobyota can be, e.g., used to analyse the interdependence between lichen cover and pine tree stands features growing in dry conditions. The research was carried out in order to study the current state, distribution, preservation and restoration of lichen pine forests. As a result of the analysis of the field materials and herbarium samples, we conducted a systematic analysis of identified lichen species and we found that all of them belong to two families Cladoniaceae Zenker and Parmeliaceae Zenker and two genders - Cladonia Hill. ex P. Browne and Cetraria Ach. The identified types of lichens belong to multiregional geoelement of the boreal type of range. The ecological analysis of lichens and their distribution in relation to environmental factors was performed. It was found that due to soil acidity, soil fertility, substrate humidity, light regime and resistance against human impact epigeous lichens of dry pine forest are as follows: either sub-acidophils or neutrophils, oligotrophs, xerophytes, heliophytes, and either oligohemerobes or mesohemerobes. According to the anatomic structure, the lichens in matter are heteromeric, and in the form of thalamus, all species are bushy with transitional forms. The results of the floristic analysis can be the basis for carrying out the monitoring studies of epigeous lichenobyota of the Cladonio-Pinetum Juraszek 1927 in Western Polissya.

Keywords: taxonomy of lichens; epigeous lichens; Cladonio-Pinetum Juraszek 1927; Cladonia Hill.; Western Polissya. 